Finnish affairs are largely in the hands of those who have been distinguished in technology or the academic field, and the conspicuous virility and efficiency in the industry and the culture of Finland may arise partly from this circumstance. They also owe much to the courage and energy of the Finnish people. The open-hearted hospitality towards the many guests on the occasion of this festival was also characteristic.

\section{川b OBITUARIES}

\author{
Prof. C. L. Fortescue, O.B.E.
}

Prof. C. L. Forifespere's death on September 22, only three years aft $h$ his retirement from the chair of electrical Angingring at the Imperial College of Science and rejhology, London, came as a shock to his many frends and former colleagues and staff. He was bon in 1881 and educated at Oundle School and Christ's College, Cambridge, where he obtained a Arst, class in the Mechanical Sciences Tripos. He plaỳd dn active part in school and College life, was a kepn oarsman and reached the 'trial eights' while at Cambridge. This keen interest in student activities and particularly rowing never diminished, but probably increased during his later years, and he was rarely away from the river when Imperial College crews were racing.

On leaving Cambridge he spent some years at Messrs. Siemens dynamo works and as instructor in electrotechnics and applied mechanics at H.M. Torpedo and Gunnery Schools, Portsmouth. During 1911-22 he was professor of electrical engineering at the Royal Naval College, Greenwich, and during this period, in addition to his academic and administrative duties, he carried out experimental work connected with wireless telegraphy during the First World War.

In 1922 he was appointed professor of electrical engineering at the Imperial College of Science and Technology, London. He was the third to occupy this position since 1885 , the two previous occupants being Profs. W. E. Ayrton and T. Mather. During the whole of the twenty-four years that he was professor and head of the Flectrical Engineering Department he was indefatigable in his work for the College and never seemed to begrudge the long hours he spent in the Department. He was always accessible to the students and ready to help them in any way that was possible. As a lecturer and teacher he was probably more successful with the advanced and postgraduate students than with those in the earlier years, who, in many cases, found his methods of dealing with electrical engineering somewhat difficult to appreciate. He will, generally speaking, be remem. bered at the Imperial College for his very strenuous work in connexion with the teaching of the subject of telecommunications at the undergraduate stage and the development of facilities for study and research in this subject for postgraduate students.

This development was so successful that it can be stated that the Electrical Engineering Department of the Imperial College provided a more thorough course of education in the subject of telecommunications than any other college or university in Great Britain, and students from all over the world were attracted both to the undergraduate and post. graduate courses.

As a professor of the University of London, he took very seriously the many duties which fell to his lot, and devoted a great deal of care and attention to the work of the many committees and boards of which he was a member. He served on the Senate of the University, was dean of the Faculty of Engineering and chairman of the Board of Studies in Electrical Engineering.

In 1942 Prof. Fortescue was elected president of the Institution of Electrical Engineers, which was a fitting recognition not only of his professional standing and academic qualifications but also of the devoted work he had done for the Institution for very many years.

Prof. Fortescue very rarely took any rest from his work, and since his retirement in 1946 he had been active in the service of the University and also at Southampton Technical College in connexion with the development of courses in telecommunications, electronics and electrical measurements. $\mathrm{He}$ is survived by his wife, son and daughter.

\section{A. Rushton}

\section{WE regyet to announce the following deaths :}

Sir Bobert Pickard, F.R.S., formerly director of reserph, British Cotton Industry Research Asso. ciaston, on October 18, aged seventy-six.

Prof. Ida Ward, C.B.E., emeritus professor of West African languages in the University of London, on October 10, aged sixty-nine.<smiles>[76Br-]</smiles>

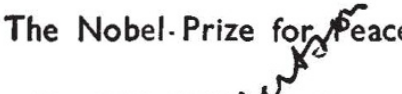

The Nobel Priz for Peace (1949) has been awarded to the Right H) h. Lord Boyd-Orr. Lord Boyd-Orr's scientific life gen be divided into certain fairly welldefined phises. There is first the period of finishing off the work which he began in the Institute of Physioldgy of the University of Glasgow. His most imfertant contribution at that time was made in colla oration with Prof. E. P. Cathcart and was concerned with the "Energy Expenditure of the Infantry Recruit in Training"; then he commenced the study of the mineral requirements of farm animals along with Walter Elliot, Arthur Crichton and others. This culminated in the production of a

\section{and VIEWS}

stimulating book entitled "Minerals in Pastures and their Relation to Animal Nutrition"- - a book which set the Empire thinking and working on its pasture problems. About 1924 Boyd-Orr began to apply his knowledge of mineral nutrition in farm animals to allied problems in children and native populations, and in 1930 along with Miss Clark he published a dietary survey of 607 families in seven cities and towns in Scotland. A little later the problem of nutrition in relation to susceptibility to disease exercised his mind, and his work in this and other spheres was recognized by his admission to the fellowship of the Royal Society in 1932. Three years later he was created a Knight Bachelor.

In 1936 Boyd-Orr published his epoch-makin survey of adequacy of diet in relation to income 